\title{
Towards an Inclusive Anthropology of Aging
}

W kierunku właczajacej antropologii starzenia sie

As a discipline that takes the fact of human diversity as a fundamental principle, anthropology aims to understand, explain, and sustain humanity in all its multitudes of forms. Yet what are anthropologists to do when some cultural forms are based on exclusion and discrimination, the antithesis of our discipline's commitment to radical openness? This question raises the issue of cultural and moral relativisms, a longstanding focal point of introductory courses in sociocultural anthropology. Although less directly, this also raises the issue of incommensurability or multiple forms of rationality, another enduring element of debates in sociocultural anthropology (e.g., Evans-Pritchard 1968; Good 1986). More recent work on partial connections (Strathern 2005) and radical difference (de la Cadena 2015) has suggested that "kaleidoscopic" and "fractal" perspectives can offer non-reductive modes of anthropological understanding that include the possibility of incommensurability and untranslatability, but also refuse the totalizing boundaries that create distinct units, through an insistence on relationality as primary. If anthropology (and anthropologists) are epistemologically committed to openness and the inclusion of incommensurable worlds, how are we to reconcile this principle with the study of enduring forms of exclusion and discrimination, or of groups that promote the same? This brief commentary offers reflections on these issues through the lens of the anthropology of aging, towards the goal of a more inclusive anthropology and society.

Old age and aging processes have long been part of anthropological research, both empirically and theoretically. Aging appears in the ethnographic record in 
multiple ways, such as through discussions of age sets and grades (Fortes 1970), analysis of human development in cultural contexts (Clark 1967), study of generational power relations (Kertzer, Keith 1984), study of rituals and rites of passage (Myerhoff 1978), analysis of the complex intertwining of biology and culture (Lock 1993), and comparative study of understandings of gender, body, and self over time (Kaufman 1986; Lamb 2000). ${ }^{1}$ In these studies, old age comes to matter in how it shapes kinship, political economy, bodies, gender, and experience. Sometimes, belonging to an aged category can bestow respect and dignity, as when older adults are described as "wise," while at other times, the category of old age can generate discrimination, as when older adults are labeled as "senile." In these examples of wisdom and senility, it is older adults' relationship to the past that shapes how they are perceived in the present. This relationship to the past can take on generational contours in the context of sociopolitical change, as in eastern Europe during the lifetimes of the current oldest generations. ${ }^{2}$ Despite this range of ways that aging comes to matter in anthropology, it can still occur that older adults are created as an anthropological other.

On the theoretical level, there are ways that anthropologists and scholars can perpetuate analytic othering of older adults. Since I began studying aging over fifteen years ago, I have tried to heed anthropologist Lawrence Cohen's (Cohen 1994) caution against reifying "the old" as a separate category of person that makes them legible for study. This epistemological critique of the gerontological and geroanthropological enterprise (see also Estes 1979, 1993; Luborsky, Sankar 1993) has made fundamental that my research participants are not examples of some type of anthropological "other," and that living within the category that has come to be marked as "old age" or "late life" does not intrinsically represent an alternate way of being. Rather, these critiques have encouraged me to ask how age comes to be a meaningful form of difference. Additionally, my experiences of witnessing my own grandparents' old age, late life, and death have shaped my understandings of the importance of intimate family habits and patterns, gendered ideals of the life course, and imaginations of a broader collective (Robbins-Ruszkowski 2016). When holding together these personal experiences and epistemological critiques, imagining my research participants as somehow "other" due to age seems downright impossible.

1 These categories are drawn from an article on the anthropology of aging (Robbins-Ruszkowski 2018)

2 I thank one of the anonymous reviewers of this essay for encouraging discussion of the multiple valences of identity categories, and of generational authority, especially in Poland and central-eastern Europe. Identity categories can both disempower and empower, as evident in activism based on stigmatized or marginalized identities (e.g., gay rights and feminist activism, or in the case of later life, the Gray Panthers [see Sanjek 2009]) 
And yet there have been meaningful forms of difference in my ethnographic work. As an American anthropologist in Poland, there were linguistic and cultural boundaries throughout my fieldwork. As a white American anthropologist working and conducting research in post-industrial majority-African American cities in the upper-Midwest of the United States, while living in a majority-white college town, there were also linguistic and cultural boundaries. Although they were different in both form and content from those I experienced while doing research in Poland, they were boundaries nevertheless. Rather than compare the Polish and American field sites to each other, I would like to hold them together to ask: in which moments did these differences come to matter for the doing of anthropology, and how did they coexist or intersect with forms of difference related to age? Exploring such questions brings me back to the opening framing of incommensurability as it relates to the empirical field of aging.

On the empirical level, there are also issues of exclusion and incommensurability in the anthropology of aging. I have chosen the two examples here not because they exhaust the possibilities of these forms of exclusion, but because they are representative of issues that appeared during research on aging in Poland and the US. First, there is ageism, which can serve to exclude older people from many aspects of sociocultural life in many parts of the world. For instance, social policies or educational institutions can marginalize or discriminate against older workers, and younger people can assume that older adults are less competent or capable because of their appearance. Second, some older adults themselves can have exclusionary or hateful viewpoints (lest we reproduce ageist stereotypes, however, it is important to note that this is true for people across the life course). This can likewise take many forms, as when older people make stereotypical comments that were socially acceptable in some circles at earlier points in their lives, or support political parties that support exclusionary social policies. Both these empirical issues were present in my fieldwork.

During my ethnographic research in Poland, older people commonly shared experiences of ageism in both public and private spheres. Some older Poles felt that they were invisible to their younger peers or kin, or were valued only for their grandparental caring labor, but that their full personhood was not recognized. Despite these experiences, some older Poles did find ways to challenge these forms of marginalization. One way this occurred was through participating in Universities of the Third Age, in which older people gathered to learn and socialize among peers, and sometimes in intergenerational contexts (RobbinsRuszkowski 2013). Another way this occurred was through organizations promoting active aging and aktywność in late life, in which older people gathered to 
engage in health-promoting behaviors, socialize, and directly counter negative stereotypes (Robbins-Ruszkowski 2015). A third way that this occurred was perhaps more unexpected, in which older people living in institutional care created meaningful social relations with others (fellow residents or patients, staff, visitors) in ways that recalled earlier forms of social connection (Robbins in press). In Flint, Michigan, during the water crisis in which the municipal drinking water supply was poisoned with lead and other contaminants, older adults felt invisible because the public-health response initially focused on responses to help infants, young children, and pregnant women, since the neurotoxic effects of lead are most severe for these populations. Yet over time, organizations focused on older adults built resources and created programming aimed at assisting and empowering older adults, while older adults themselves relied on existing forms of sociality, creating new relations of care (Robbins, Perry, Seibel 2017). In all these cases, ethnographic awareness highlights how ageism created not just forms of exclusion, but also possibilities for new forms of inclusion as well.

Sometimes, it is possible for groups that themselves experience discrimination to practice their own forms of exclusion, thus bringing together the two concerns raised at the outset of this essay. For instance, I found that it was not uncommon for older adults in Poland to make comments that were discriminatory on the basis of race, ethnicity, or religion. Additionally, many of my research participants supported political parties that promoted exclusionary nationalist policies. Some younger friends would dismiss these comments as characteristic of that generation, as something to be expected. But not all older Poles made such comments, nor do all older Poles vote in a uniform bloc, although there are strong generational voting patterns. However, such generational explanations are necessarily partial and incomplete. The fact of old age does not inherently connect to ethnic stereotypes or conservative political views. Rather, ethnographic analysis revealed that such political views are part of social relations that shape the spatiotemporal contours of moral personhood (Robbins in press; Robbins-Ruszkowski 2014). This explanation does not excuse such views, but the holistic lens of anthropology can help to make them visible.

Yet as I spent more time in Poland, and developed enduring social relations with people there, it became increasingly difficult to participate in ethnographic encounters with people espousing such exclusionary views. I found myself needing to have more time between interviews and engaging more frequently and actively in my own social networks with people who held perspectives that were not hateful. I also found that I could no longer only share the explanations for older people's discriminatory beliefs, but also had to discuss the broader effects of the policies of such nationalist political parties (Robbins-Ruszkowski 2016). 
This resulted in a sense of social distance from some research participants with whom I had previously felt more of a connection.

I have come to understand this recognition of distance as perhaps more reflective of the truth of ethnographic encounters. Indeed, perhaps it is this disciplinary desire for ethnographic intimacy that creates our discomfort with doing research with people who hold exclusionary or hateful views. What would it mean to practice an anthropology that both values ethnographic intimacy but also holds dear its limits? What if incommensurability were not a theoretical puzzle to be solved but an empirical fact to be welcomed, documented, and explored? Could such a reorientation that begins from a place of radical difference help to work towards a more inclusive anthropology? Perhaps such an epistemological stance could help us to create not only a more inclusive anthropology, but also a more inclusive society.

I would like to thank the Wayne State University students in my Winter 2020 anthropological theory seminar for helping to shape my thinking on radical difference.

\section{Bibliography}

Clark, M. (1967). The Anthropology of Aging, a New Area for Studies of Culture and Personality. The Gerontologist, 7(1), 55-64.

Cohen, L. (1994). Old Age: Cultural and Critical Perspectives. Annual Review of Anthropology. 23(1), 137-158.

de la Cadena, M. (2015). Earth Beings: Ecologies of Practice Across Andean Worlds. DurhamNC: Duke University Press.

Estes, C.L. (1979). The Aging Enterprise. San Francisco-CA: Jossey-Bass.

Estes, C.L. (1993). The Aging Enterprise Revisited. The Gerontologist, 33(3), 292-298.

Evans-Pritchard, E.E. (1968). Witchcraft, Oracles and Magic Among the Azande. Oxford: Oxford Clarendon Press.

Fortes, M. (1970). Time and Social Structure and Other Essays. London: Athlone.

Good, B. (1986). Medicine, Rationality, and Experience: An Anthropological Perspective. Cambridge: Cambridge University Press.

Kaufman, S.R. (1986). The Ageless Self: Sources of Meaning in Late Life. Madison-Wis.: University of Wisconsin Press.

Kertzer, D.I., Keith, J. (eds.) (1984). Age and Anthropological Theory. Ithaca-NY: Cornell University Press. 
Lamb, S. (2000). White Saris and Sweet Mangoes: Aging, Gender, and Body in North India. Berkeley-CA: University of California Press.

Lock, M.M. (1993). Encounters with Aging: Mythologies of Menopause in Japan and North America. Berkeley-CA: University of California Press.

Luborsky, M.R., Sankar A. (1993). Extending the Critical Gerontology Perspective: Cultural Dimensions. Introduction. The Gerontologist, 33(4), 440-444.

Myerhoff, B.G. (1978). Number Our Days: Culture and Community Among Elderly Jews in an American Ghetto. New York: Dutton.

Robbins, J.C. (in press). Aging Nationally in Contemporary Poland: Memory, Kinship and Personhood. New Brunswick-NJ: Rutgers University Press.

Robbins-Ruszkowski, J.C. (2013). Challenging Marginalization at the Universities of the Third Age in Poland. Anthropology \& Aging, 34(2), 157-169.

Robbins-Ruszkowski, J.C. (2015). “Active Aging” as Citizenship in Poland. In: R. Marback (ed.), Generations: Rethinking Age and Citizenship (pp. 270-286). Detroit-MI: Wayne State University Press

Robbins-Ruszkowski, J.C. (2016). Exploring the "Shadow Side" of Ethnographic Research on Aging in Poland. Lud, 100, 143-152.

Robbins, J.C., Perry, T., Seibel, K. (2017). Sustaining Life in an Anthropogenic Crisis: The Role of Kinship among Older Adults in the Flint Water Crisis. Part of the panel "Kinship Labor and Livelihood: The Political Economy of Obligation and Dependency." Annual Meeting of the American Anthropological Association. November 29-December 3. Washington-D.C.

Sanjek, R. (2009). Gray Panthers. Philadelphia-PA: University of Pennsylvania Press.

Strathern, M. (2005). Partial Connections: AltaMira Press.

\section{Summary}

Given anthropology's disciplinary commitment to diversity and openness, studying cultural formations that are based on exclusion and discrimination can pose epistemological challenges. Such issues are at the heart of longstanding disciplinary debates about cultural and moral relativism, incommensurability, and multiple forms of rationality. This essay explores how these issues have emerged during long-term ethnographic research on aging in Poland and the US, and suggests that beginning from a place of radical difference might offer possibilities for a more inclusive anthropology.

Key words: exclusion, radical difference, ethnography, aging, Poland, US

\section{Streszczenie}

Biorąc pod uwagę głębokie zaangażowanie antropologii jako dyscypliny naukowej w kwestie różnorodności i otwartości, badanie formacji kulturowych opartych na wykluczeniu i dyskryminacji może stanowić wyzwanie epistemologiczne. Problemy te od wielu lat są sednem wewnątrzdyscyplinarnych dysput na temat kulturowego i moralnego relatywi- 
Jessica C. Robbins Towards an Inclusive Anthropology of Aging

zmu, niewspółmierności oraz różnorodnych form racjonalności. W artykule omówiony jest sposób, w jaki problemy te wyłoniły się podczas długookresowych etnograficznych badań nad starzeniem się prowadzonych w Polsce i Stanach Zjednoczonych, a także wyłaniająca się sugestia, że punkt wyjściowy w postaci radykalnej różnicy może dać szansę ewolucji bardziej włączającej antropologii.

Słowa klucze: wyłączenie, radykalna różnica, etnografia, starzenie się, Polska, US

Tłumaczenie: Klaudyna Michałowicz 